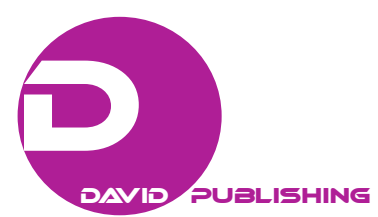

\title{
Decomposition Relationship Between Factors of Production, FDI and GDP for Czech Republic_-In VECM
}

\author{
Aneta Kosztowniak \\ Kazimierz Pułaski University of Technology and Humanities in Radom, Radom, Poland \\ National Bank of Poland, Warsaw, Poland
}

\begin{abstract}
This article contains analysis of relationship between factors of production and GDP in the Czech Republic in the period 1994-2015. The VECM model uses the variance decomposition function in order to determine the explanation degree of changes in GDP and the remaining eight macroeconomic indicators were examined in the Czech Republic in the years 1994-2015. The empirical research confirmed that the consumption demand and trade had a strong impact on GDP, towards a weak FDI impact on economic growth results from rapid fluctuations in FDI inflows and unfavourable structure of these investments. These conditions do not guarantee a stable and effective investment cycle, including new reinvestments ${ }^{1}$.
\end{abstract}

Keywords: FDI, GDP, Czech Republic, VECM, the variance decomposition function

\section{Introduction}

The main attention of this paper is focused on the research whose factors of production have a strong impact on economic growth and FDI inflows in Czech Republic in the period 1994-2015. The answer to this question is very important for economic policy to sustain the growth rate. However, both the FDI theory and empirical studies for individual countries indicate that the inflow of such investment entails different economic effects.

In this article, we use methods known from literature on international economics and international finance, and econometric methods like the VECM (Vector Error Correction Method) model with variance decomposition analysis. The research bases on statistics from the OECD, UNCTAD, and IMF Internet databases.

\section{Literature Review and Empirical Studies}

International economic literature presents many theories explaining the role of FDI in the process of economic growth in host countries. The effect between FDI and GDP can be either favourable or unfavourable.

\footnotetext{
Acknowledgements: The views expressed in this paper are the views of the author and do not necessarily reflect those of the National Bank of Poland.

Aneta Kosztowniak, Ph.D., assistant professor of Economics, Department of Economic Policy and Banking, Kazimierz Pułaski University of Technology and Humanities in Radom, Radom; Statistical Department, National Bank of Poland, Warsaw, Poland.

Correspondence concerning this article should be addressed to Aneta Kosztowniak, Department of Economic Policy and Banking, University of Technology and Humanities in Radom, 31 Chrobrego Street, Radom 26-600, Poland.

1 This paper presents author's the additional empirical findings towards the paper under the title: Modelling GDP and FDI for Czech Republic - Impulse Response Function in VECM, which could not be presented on account of volume restrictions of the article.
} 
Several studies find a clear positive link, while others do not. Moreover, there are several potential ways in which FDI can cause growth. The neoclassical models of growth as well as endogenous growth models provide the basis for most of the empirical work on the FDI-growth relationship (Ozturk, 2007). The relationship has been studied by explaining four main channels i.e. determinants of growth, determinants of FDI, role of multinational firms in host countries, and direction of causality between the two variables (Chowdhury \& Mavrotas, 2005). These theories generally come from two sources: factor accumulation and total factor productivity (TFP) growth (Felipe, 1997). The neoclassical growth theory (Solow, 1999) recognizes the role of FDI, whereas the endogenous growth literature points out that FDI cannot contribute to economic growth only through capital formation and technology transfers (Blomstrom, Lipsey, \& Zejan, 1996; Borensztein, De Gregorio, \& Lee, 1995) but also does so through the augmentation of knowledge through labour training and skill acquisition (De Mello,1999). The endogenous growth models concentrate on three main channels through which FDI affects growth. Firstly, FDI increases capital accumulation in the receiving country by introducing new inputs and technologies (Dunning, 1993; 1996; Borensztein, De Gregorio, \& Lee, 1998). Secondly, it raises the level of knowledge and skills in the host country through labour and manager training (De Mello,1999). Thirdly, FDI increases competition in the host country industry by overcoming entry barriers and reducing the market power of existing firms.

Many authors tried to explain the relationship between FDI and growth. Landesmann (2003) found out that in the Czech Republic, Hungary, Poland, and Slovenia, foreign subsidiaries account more for a higher share of sales in the medium and high-tech branches than in the low-tech or the resource-intensive ones, while the presence of FDI across other CEE countries is very uneven and so is its role in facilitating the upgrading of the CEE countries' industrial structures. According to Baldwin (2012) these productivity improvements due to FDI inflows may not necessarily predestine countries more lucky in attracting FDI to high-tech industries for the long-term higher development levels. FDI may easily pull out of the countries leaving them without much home-grown economic foundations. Yet, over the last decade, a half FDI has certainly helped the CEE countries to grow faster in terms of TFP and to increase employment in high-tech industries. However, how sound and stable this specialization is in the long run is another question. Detailed analysis of FDI and productivity of firms for Czech Republic in the period 1993-1998 (Jarolim, 2000) concern a firm-level data supplied by manufacturing industry suggest, that firm with foreign participation achieved higher productivity growth rates than domestically owned firm. Among firms with foreign participation, green-field enterprises performed slightly better in terms of total factor productivity growth than firms created through merger and acquisitions. FDI's spillover effect, however, is found to be statistically insignificant, which does not support the hypothesis that foreign presence positively affects the productivity of domestically owned firms.

According to Nikolovová (2013) research for Western and CEE countries (for Czech Republic also; see: Kosztowniak, 2017) covers the time period 2001-2007, this research shows that increased FDI activity in the downstream sector leads to a change in the proportion of intermediate goods supplied by domestic producers and by multinational enterprises (MNEs) operating in the upstream sector-MNEs cover a larger of the increasing demand. This is true especially in the first half of the period studied (2001-2003). In the second half (2004-2007), domestic producers are further replaced by importers. This shows that FDI has the potential to positively influence the economy of the host country through backward inter-industry linkages, but this potential is not fully exploited yet in CEE countries, possibly due to a persisting technology gap. 


\section{Methodology of Econometric Model}

In this study we employ the methodology of VECM because it allows identifying relationship between factors of production and GDP in the Czech Republic in the years 1994-2015. The final formula for the production function was developed which looks as follows:

$$
Y_{t}=f\left(E C E H_{t}, E C E G G_{t}, G F C F_{t}, F D I_{t}, E x G S_{t}, \operatorname{ImGS}_{t}, R \& D_{t}, E m p l o y_{\cdot t}\right)
$$

where: GDP: Gross Domestic Product, FCEH: Final Consumption Expenditure of Households), FCEGG: Final Consumption Expenditure of General Government, GFCF: Gross Fixed Capital Formation, FDI: Foreign Direct Investment, ExGS: Exports of Goods and Services, ImGS: Imports of Goods and Services, R\&D: Expenditure on Research and Development, Employ: Total employment in the economy (number of persons in thousands), and t-period.

The model used consists of the dependent variable (GDP) and eight independent variables (in million USD, constant prices, 2010). The research methodology was adopted by many authors, among others by Chowdhury and Mavrotas (2005), Driffield and Jindra (2012), who analyzed the FDI effect on economic growth in host countries.

In order to verify the selection of variables (see Figure 1) for the model many tests were used: the Pearson linear correlation coefficient, the Augmented Dickey-Fuller (ADF), Engle and Granger test (Table 1), Johansen test (Johansen, 1998) (Table 2) which in this way confirmed and justified the use of the VECM model.

Table 1

Results of the Engle-Granger Co-Integration Test

\begin{tabular}{|c|c|c|c|c|c|c|c|c|c|}
\hline Specification & 1d_GDP & ld_FCEH & 1d_FCEGG & 1d_GFCF & ld_FDI & ld_ExGS & Ld_ImGS & ld_R\&D & ld_Employ \\
\hline $\begin{array}{l}\text { Null hypothesis: } \\
\text { unit root occurs }\end{array}$ & $\begin{array}{l}a=1 ; \\
\text { process } \\
\text { I(1) }\end{array}$ & $\begin{array}{l}\mathrm{a}=1 ; \\
\text { process } \\
\mathrm{I}(1)\end{array}$ & $\begin{array}{l}a=1 ; \\
\text { process } \\
I(1)\end{array}$ & $\begin{array}{l}a=1 ; \\
\text { process } \\
\text { I(1) }\end{array}$ & $\begin{array}{l}a=1 ; \\
\text { process } \\
\text { I(1) }\end{array}$ & $\begin{array}{l}a=1 \\
\text { process } \\
\mathrm{I}(1)\end{array}$ & $\begin{array}{l}a=1 \\
\text { process } \\
\text { I(1) }\end{array}$ & $\begin{array}{l}a=1 ; \\
\text { process } \\
\mathrm{I}(1)\end{array}$ & $\begin{array}{l}a=1 ; \\
\text { process } \\
\text { I(1) }\end{array}$ \\
\hline $\begin{array}{l}\text { With constant } \\
\text { test statistic } \tau \text {, } \\
\text { (asymptotic } \\
p \text {-value) }\end{array}$ & $\begin{array}{l}-3.09189 \\
(0.02718)\end{array}$ & $\begin{array}{l}-3.26278 \\
(0.01666)\end{array}$ & $\begin{array}{l}-3.04089 \\
(0.03127)\end{array}$ & $\begin{array}{l}-4.64752 \\
(0.0001015)\end{array}$ & $\begin{array}{l}-4.11549 \\
(0.0009109)\end{array}$ & $\begin{array}{l}-3.17651 \\
(0.02142)\end{array}$ & $\begin{array}{l}-3.45823 \\
(0.009155)\end{array}$ & $\begin{array}{l}-4.57151 \\
(0.0001)\end{array}$ & $\begin{array}{l}-2.62007 \\
(0.08883)\end{array}$ \\
\hline
\end{tabular}

Source: author's own compilation.

Table 2

The Johansen Test

\begin{tabular}{llll}
\hline Rank & Eigen value & Trace test $p$-value & $\mathrm{L}_{\max }$ test $p$-value \\
\hline 0 & 0.99618 & $329.89[0.0000]$ & $111.34[0.0000]$ \\
1 & 0.98183 & $218.55[0.0000]$ & $80.162[0.0000]$ \\
2 & 0.91891 & $138.39[0.0058]$ & $50.244[0.0137]$ \\
3 & 0.77643 & $88.146[0.1481]$ & $29.961[0.4410]$ \\
4 & 0.66548 & $58.185[0.2970]$ & $21.901[0.6241]$ \\
5 & 0.53377 & $36.284[0.3867]$ & $15.261[0.7289]$ \\
6 & 0.39648 & $21.023[0.3667]$ & $10.099[0.7386]$ \\
7 & 0.27978 & $10.924[0.2198]$ & $6.5640[0.5497]$ \\
8 & 0.19586 & $4.3596[0.0368]$ & $4.3596[0.0368]$ \\
\hline
\end{tabular}

Notes: Number of equations $=9$, Lag order $=1$, Case 3: Unrestricted constant. Source: author's own compilation. 

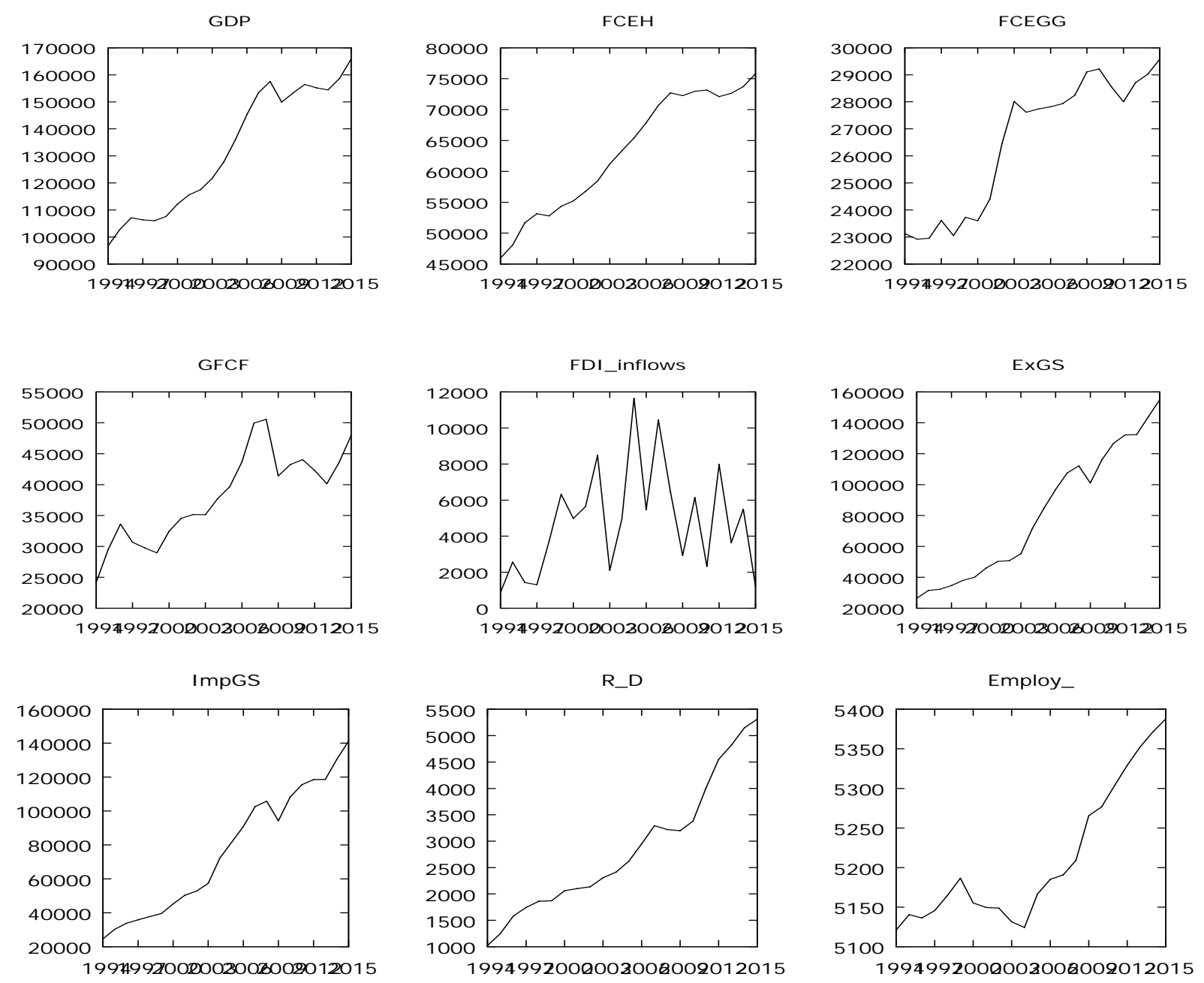

Figure 1. Time series of the model variables for the Czech Republic in the years 1994-2015. Source: author's own compilation (OECD. Stat.; UNCTAD. Stat., 2017), with the use of the Gretl program.

\section{VECM Model}

The general form of the VECM model can be written down as:

$$
\Delta Y_{t}=\Gamma_{1} \Delta Y_{t-1}+\Gamma_{2} \Delta Y_{t-2}+\ldots+\Gamma_{k-1} \Delta Y_{t-k+1}+\pi Y_{t-k}+\varepsilon_{t}=\sum_{i=1}^{k-1} \Gamma_{i} \Delta Y_{t-i}+\pi Y_{t-k}+\varepsilon_{t},
$$

where

$$
\Gamma_{i}=\sum_{j=1}^{i} A_{j}-I, i=1,2, \ldots, k-1, \Gamma_{k}=\pi=-\pi(1)=-\left(I-\sum_{i=1}^{k} A_{i}\right),
$$

$I$ is the unit matrix.

The lag order for the VAR/VECM model was determined on the basis of the following information criteria estimation: AIC, BIC, and HQC criterion. The results of these criteria showed the lag order 1 (Table 3).

While analyzing stability of the VAR/VECM model, the unit root test was carried out which indicated that in the analyzed model, the equation roots in respect of the module are lower than one. This means that the model is stable. The Ljung-Box test was used to verify the occurrence of autocorrelation between the variables of the VECM model. The results of the Ljung-Box test for the estimated models (1-9), i.e. for all examined variables, showed that the empirical $p$-levels were higher than the nominal significance level $\alpha=0.05$. This 
authorized us to state the lack of autocorrelation in the residual process.

Table 3

The Best Values of the Respective Information Criteria: AIC, BIC, and HQC

\begin{tabular}{llllll}
\hline Lag order & Loglik & $p(\mathrm{LR})$ & AIC & BIC & HQC \\
\hline 1 & 84.46738 & & $-7.838671^{*}$ & $7.341598^{*}$ & $-7.754547^{*}$ \\
2 & 84.49307 & 0.82069 & -7.736112 & -7.189332 & -7.643575 \\
\hline
\end{tabular}

Notes. The asterisk $(*)$ indicates the best (i.e. minimum) value for respective information criteria: $\mathrm{AIC}=\mathrm{Akaike}$ criterion, $\mathrm{BIC}=$ Schwarz Bayesian criterion, and HQC = Hannan-Quinn criterion. Source: author's own compilation.

\section{Empirical Findings-The Variance Decomposition Function}

In order to determine the explanation degree of changes in GDP and examine the remaining eight macroeconomic indicators in the Czech Republic in the years 1994-2015, the error variance decomposition was carried out for the VECM model variables. The adopted forecast horizon embraced 10 periods (years). This decomposition allows us to discover the system dynamics showing the most significant places in the VAR/VECM structure. It shows which shocks have the dominant effect on the standard error of each endogenous variable of the model (Table 4, Figure 2).

Table 4

Variance Decomposition for the Variable ld_GDP

\begin{tabular}{llllllllll}
\hline Time & ld_GDP & ld_FCEH & ld_FCEGG & ld_GFCF & ld_FDI & ld_ExGS & ld_ImpGS & ld_R_D & ld_Employ. \\
\hline 1 & 100.0000 & 0.0000 & 0.0000 & 0.0000 & 0.0000 & 0.0000 & 0.0000 & 0.0000 & 0.0000 \\
2 & 99.8854 & 0.0000 & 0.0096 & 0.0387 & 0.0276 & 0.0250 & 0.0104 & 0.0031 & 0.0002 \\
3 & 99.8888 & 0.0000 & 0.0093 & 0.0376 & 0.0268 & 0.0243 & 0.0101 & 0.0031 & 0.0002 \\
4 & 99.8815 & 0.0000 & 0.0099 & 0.0400 & 0.0285 & 0.0258 & 0.0107 & 0.0033 & 0.0002 \\
5 & 99.8796 & 0.0000 & 0.0101 & 0.0407 & 0.0290 & 0.0263 & 0.0109 & 0.0033 & 0.0002 \\
6 & 99.8777 & 0.0000 & 0.0102 & 0.0413 & 0.0294 & 0.0267 & 0.0111 & 0.0034 & 0.0002 \\
7 & 99.8765 & 0.0000 & 0.0103 & 0.0417 & 0.0297 & 0.0269 & 0.0112 & 0.0034 & 0.0002 \\
8 & 99.8756 & 0.0000 & 0.0104 & 0.0421 & 0.0300 & 0.0272 & 0.0112 & 0.0034 & 0.0002 \\
9 & 99.8748 & 0.0000 & 0.0105 & 0.0423 & 0.0301 & 0.0273 & 0.0113 & 0.0034 & 0.0002 \\
10 & 99.8743 & 0.0000 & 0.0105 & 0.0425 & 0.0303 & 0.0274 & 0.0114 & 0.0035 & 0,0002 \\
\hline
\end{tabular}

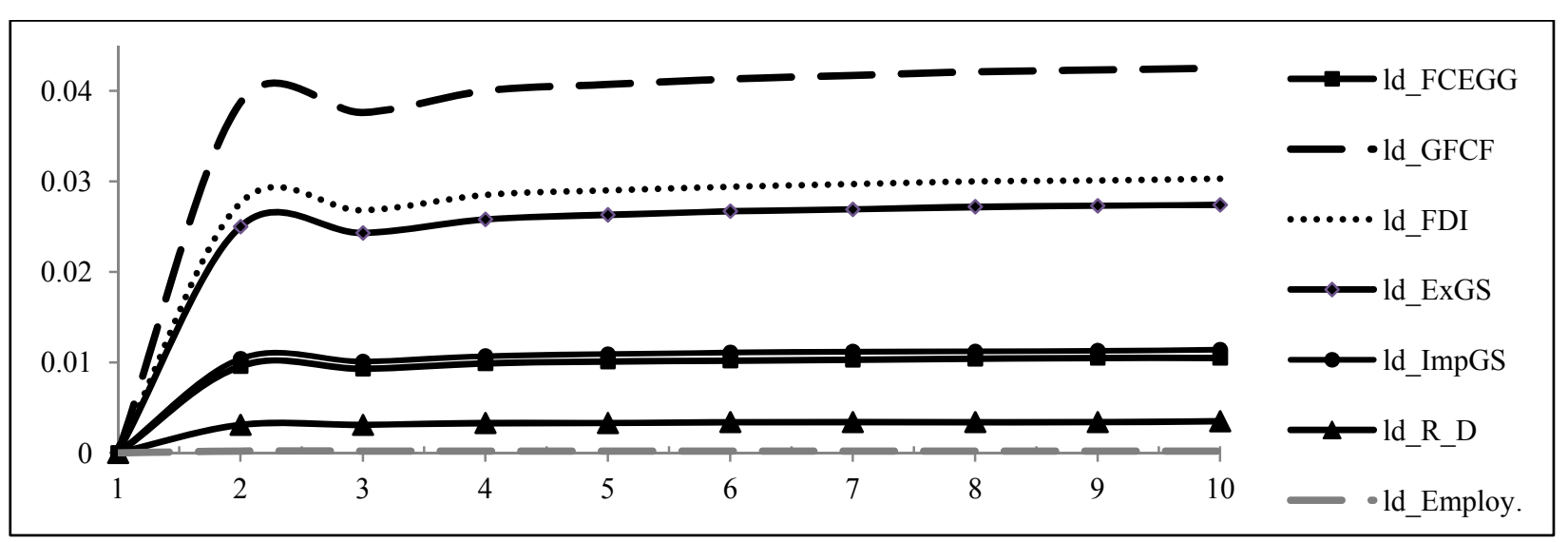

Figure 2. Variance decomposition for the variable ld_GDP.

The calculations of the GDP variance decomposition made on first differences of the logarithms show that growth dynamics was explained to the greatest extent by the variances of own GDP forecasts $(100.0 \%$ in period 
1 and $99.9 \%$ in periods $2-10)$ and from period 2 by dynamics of: GFCF $(0.04 \%)$, FDI inflows $(0.03 \%)$, and ExGS $(0.02 \%)$.

Next, calculations of the FDI variance decomposition indicate that to the greatest extent growth dynamics in period 1 was explained by the variance of error of own forecasts of FDI inflows (78.0\%), then of GFCF (15.5\%), and FCEH (5.3\%). In period 2 more significance could be ascribed to: ExGS (12.4\%), at GFCF $(10.7 \%)$, FCEGG (9.3\%), and FCEH (6.0\%). In period 10 the explanation degree for FDI inflow, apart from its own changes (44.3\%), first of all depended on: ExGS (17.5\%), FCEGG (14.3\%), and FCEH (7.8\%), and ImGS (7.3\%) (Table 5, Figure 3).

Table 5

Variance Decomposition for the Variable ld_FDI

\begin{tabular}{llllllllll}
\hline Time & ld_GDP & ld_FCEH & ld_FCEGG & ld_GFCF & ld_FDI. & ld_ExGS & ld_ImpGS ld_R_D & ld_Employ. \\
\hline 1 & 0.0113 & 5.3801 & 1.0583 & 15.5054 & 78.0448 & 0.0000 & 0.0000 & 0.0000 & 0.0000 \\
2 & 2.4641 & 6.0579 & 9.2999 & 10.7469 & 52.2560 & 12.3961 & 5.1350 & 1.5592 & 0.0849 \\
3 & 2.6160 & 6.7436 & 10.6200 & 7.9717 & 51.3632 & 13.3724 & 5.5395 & 1.6819 & 0.0916 \\
4 & 2.9091 & 7.0833 & 11.9303 & 6.4063 & 48.5642 & 14.9377 & 6.1879 & 1.8788 & 0.1023 \\
5 & 3.0445 & 7.3269 & 12.6446 & 5.3492 & 47.3663 & 15.6888 & 6.4990 & 1.9733 & 0.1075 \\
6 & 3.1551 & 7.4927 & 13.1864 & 4.6137 & 46.3508 & 16.2918 & 6.7488 & 2.0491 & 0.1116 \\
7 & 3.2330 & 7.6175 & 13.5779 & 4.0645 & 45.6453 & 16.7187 & 6.9257 & 2.1028 & 0.1145 \\
8 & 3.2943 & 7.7134 & 13.8833 & 3.6415 & 45.0868 & 17.0543 & 7.0646 & 2.1450 & 0.1168 \\
9 & 3.3427 & 7.7897 & 14.1252 & 3.3048 & 44.6468 & 17.3193 & 7.1745 & 2.1784 & 0.1186 \\
10 & 3.3822 & 7.8519 & 14.3224 & 3.0307 & 44.2872 & 17.5357 & 7.2641 & 2.2056 & 0.1201 \\
\hline
\end{tabular}

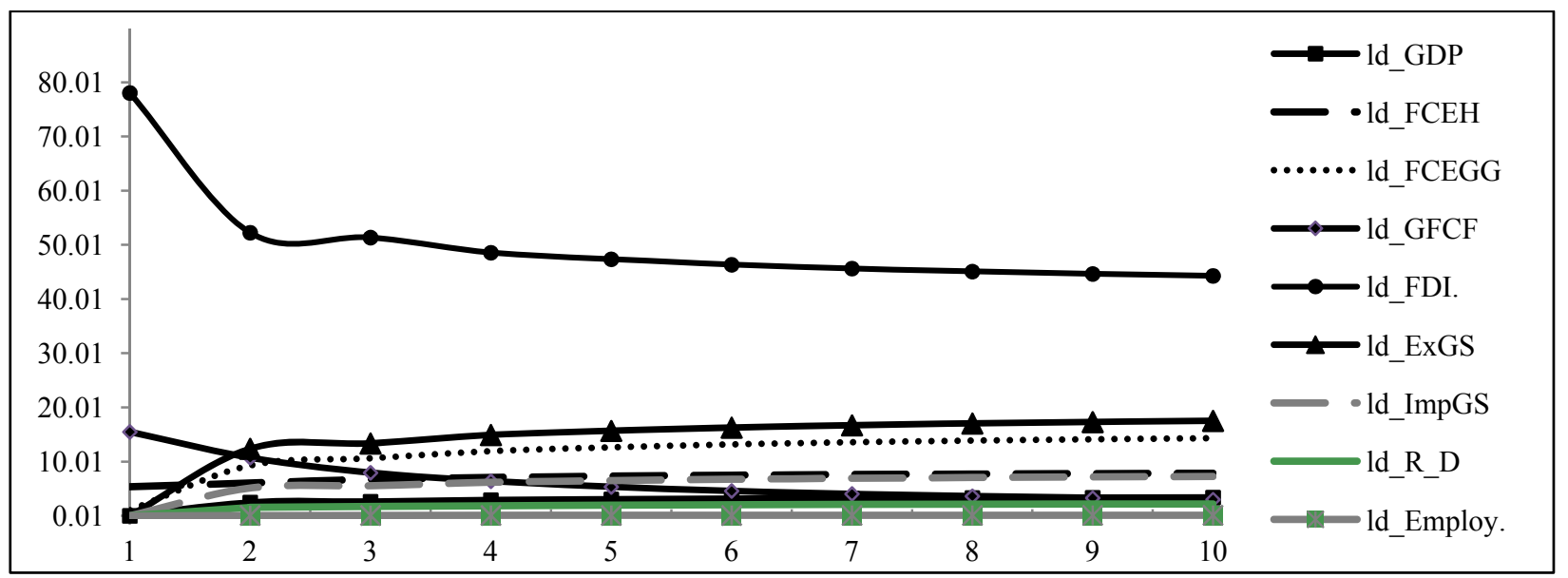

Figure 3. Variance decomposition for the variable ld_FDI.

\section{Potentially Causes of Weak Impact of FDI Inflows on Economic Growth}

Changes in the value of FDI inflows in respect of GDP in the Czech Republic in the years 1994-2015, in absolute terms (million USD) and (\% GDP) are presented in Figure 4. As far as the share of foreign capital in replenishing shortages in internal capital accumulation of the Czech Republic is concerned, in fact, since the early 2000 s the significance of this replenishment has systematically decreased.

Whereas in the years 1994-2002 the ratio of the FDI inflows to GDP grew from $1.8 \%$ to $10.4 \%$, and in 2005 it still stood at the level of $8.6 \%$, in the following years it clearly decreased. In 2009 the said ratio stood at 
$1.4 \%$, in 2010 it fell to $1.0 \%$, and in 2015 it stood at $0.7 \%$ of GDP. Nevertheless, it should be noted that in the remaining countries of the Visegrad group, when we compare the 2000s to the 1990s, the ratio of FDI inflows to GDP also revealed the falling trend (Figure 5).

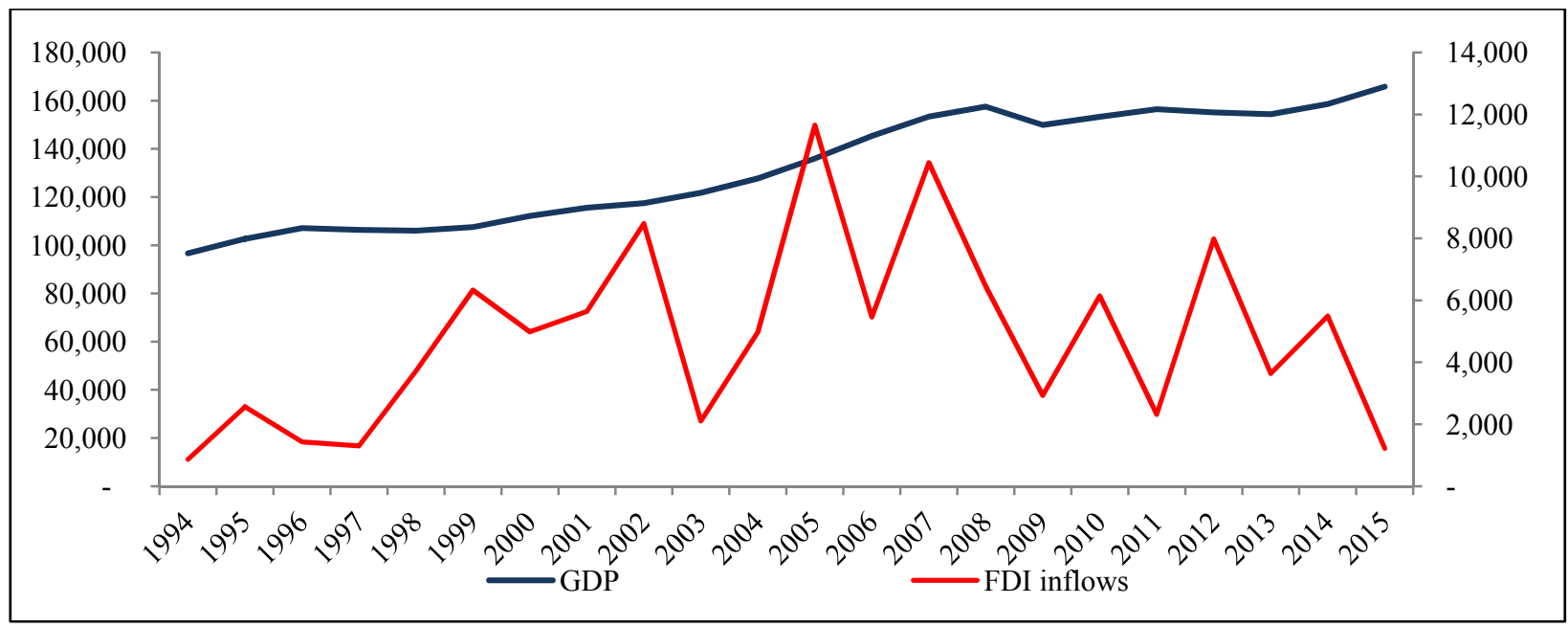

Figure 4. GDP and FDI inflows to the Czech Republic in the period 1994-2015 (million USD). Notes: Lines = left-hand scale (level of GDP), right-hand scale (level of FDI inflows). Source: author's own compilation: OECD (2017) and UNCTAD (2017).

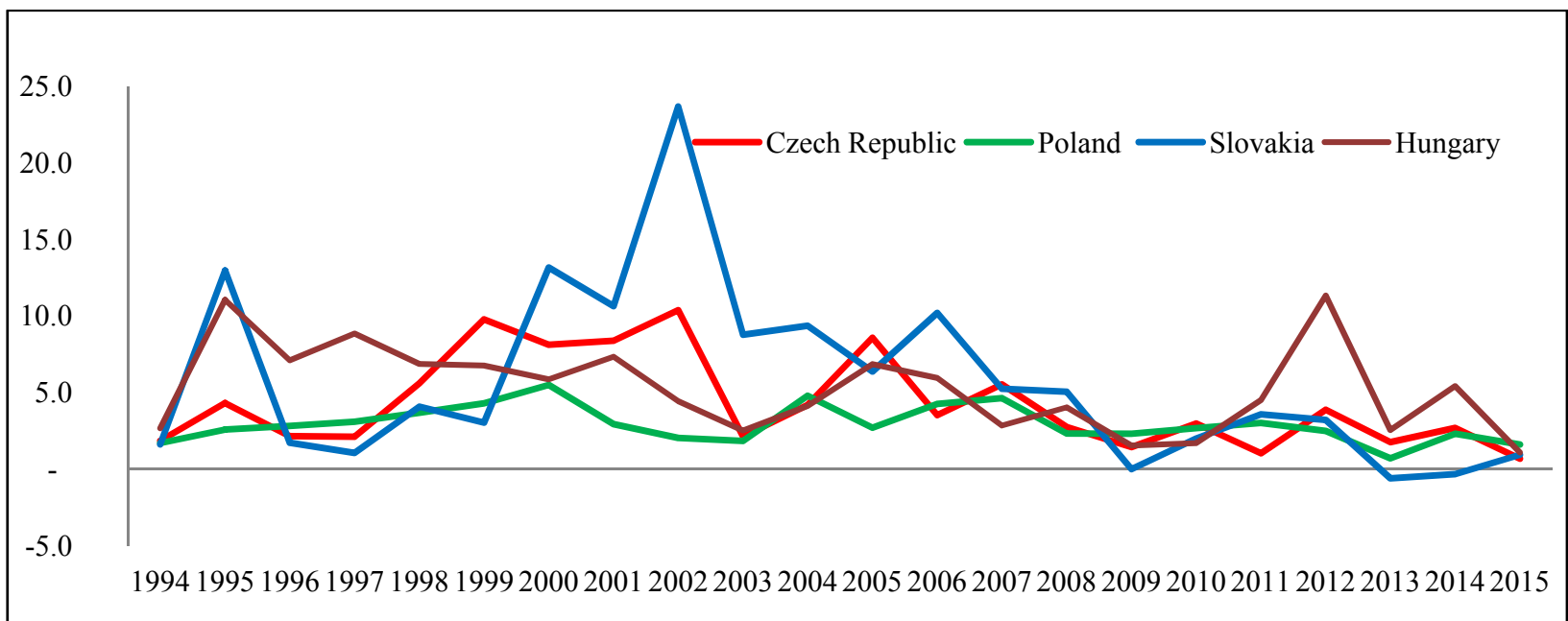

Figure 5. FDI inflows in the Visegrad countries in period 1994-2015 (\% GDP). Source: author's own calculations: UNCTAD (2017).

The relatively weak impact of FDI on economic growth in the Czech Republic can be accounted for also by the changes in the structure of inflowing investment. Considering the division of FDI by financial instruments in the structure of the said investment, a considerable increase of the share of debt instruments could be observed in particular years. Naturally these instruments including credits and loans, debt securities, and other outstanding payments between entities were connected by the direct investment relationship guarantee their correct functioning. However, in the proper FDI structure, the share of debt instruments usually stands at ca. 30\%. At higher shares of debt instruments and at the same time at lower shares of capital, the FDI impact on GDP growth may weaken. In the case of the Czech Republic, the shares of debt instruments in FDI 
amounted to $60.28 \%$ in 2008 , or to $58.83 \%$ in 2013 . Their reduction to $-27.43 \%$ in 2015 may indicate deliberate restructuring undertaken by foreign investors within the framework of corporate groups resulting, for example from tax optimization (Figure 6).

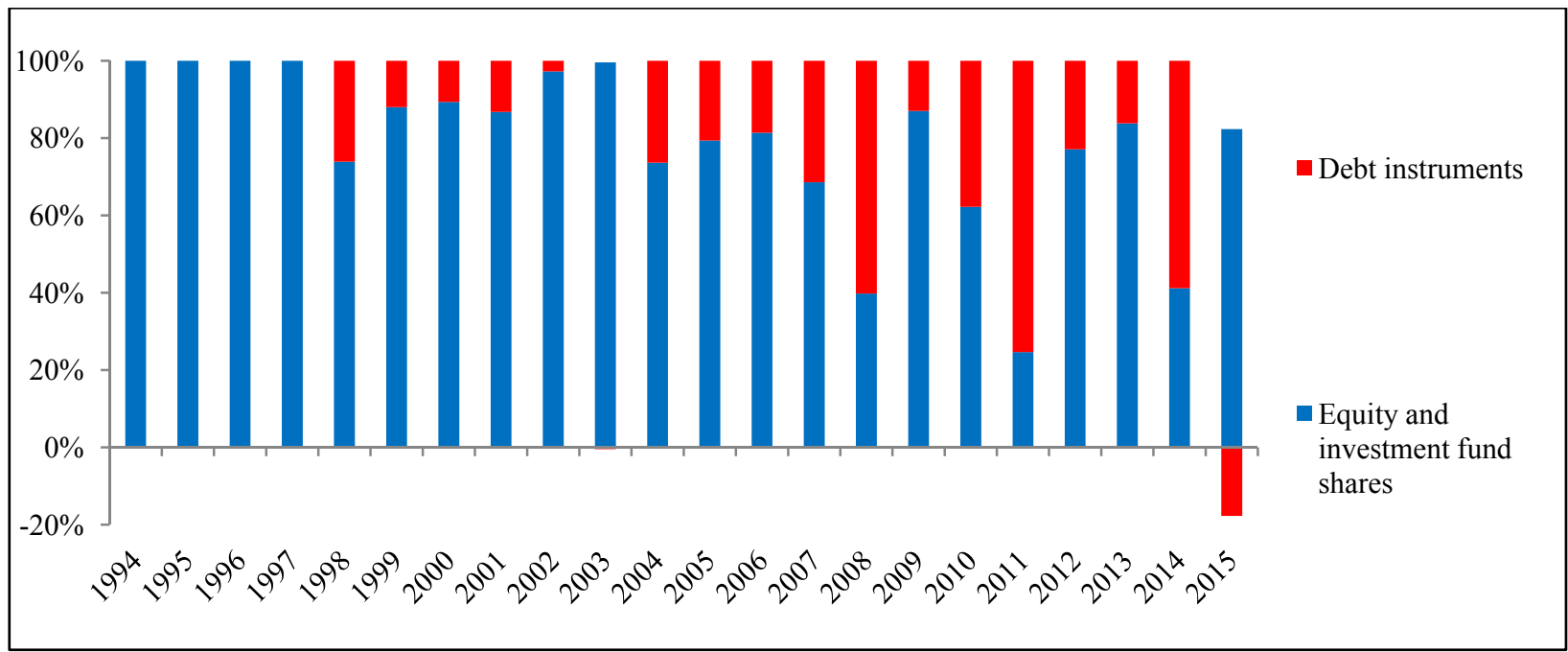

Figure 6. Structure of FDI inflows to the Czech Republic by financial instruments in the years 1994-2015 (\%).

Source: author's own calculations (IMF, 2017).

Referring to, among others, the theories of J. H. Dunning or T. Ozawa, the conditions of stable and long-term FDI inflows have not been met in the case of the Czech Republic. This means that in economy the foreign capital in the form of FDI did not support the transition of economy from the investment phase to the innovation phase. Thus, the said investment did not support development of the Czech economy which hosted it. An attempt at econometric examination of the FDI structure impact on economic growth in the Czech Republic with the use of the VAR/VECM model will be the future research task for the authoress.

\section{Conclusions}

Analysis of the production function (GDP) model for the Czech Republic in the years 1994-2015 with particular emphasis on FDI revealed, among others, important conclusions for their application in economic policy of the country. The GDP variance decomposition proved that the strongest impact on future changes was exerted by own GDP_forecast errors. FDI significance for growth was small. This means that in the years 1994-2015 FDI inflows did not stimulate economic growth in the Czech Republic. The FDI inflow responses were stronger in the case of impulses coming from: household consumption expenditure and exports and imports of goods and services. Investment policy in respect of FDI requires a change to be able to contribute effectively to economic growth of the Czech Republic. In the authoress' opinion, to make FDI inflows have a more advantageous effect on economic growth it is necessary to: stabilize FDI inflows in the long-term, increase the value of FDI inflows (FDI to GDP ratio) in order to achieve their higher share in capital accumulation, and improve structure (quality) of FDI inflows and in conclusion, it is important to make foreign direct investors lengthen the investment cycle and increase re-investment in Czech economy. 


\section{References}

Baldwin, R. (2012). Global supply chains: Why they emerged, why they matter, and where they are going. CTEI Working Papers CTEI-2012-13. The Graduate Institute Geneva, Centre for Trade and Economic Integration, p. 1-35.

Blomstrom, M., Lipsey, R. E., \& Zejan, M. (1996). Is fixed investment the key to economic growth? Quarterly Journal of Economics, 111, 269-276.

Borensztein, E., De Gregorio, J., \& Lee, J. W. (1995). How does foreign direct investment affect economic growth? NBER Working Paper, No. 5057.

Boresztein, E., De Gregorio, J., Lee, J. W. (1998). How does foreign direct investment affect economic. Journal of International Economics, 45.

Chowdhury, A. \& Mavrotas, G. (2005). FDI and growth: A causal relationship, United Nations University. WIDER, Research Paper. No. 25.

De Mello Jr, L. R. (1999). Foreign direct investment-led growth: Evidence from time series and panel data. Oxford Economic Papers, 51(1), 133-151.

Driffied, N. \& Jindra, B. (2012). Challenging the production function approach to assess the developmental effects of FDI. European Journal of Development Research and Training Institutes, 24, 32-37. EADI, Geneva, U.K.

Dunning, J. H. (1993). Multinational enterprises and the global economy. New York: Addison-Wesley Publishing Company.

Dunning, J. H., \& Narula, R. (1996). The investment development path revisited: Some emerging issues. In J. H. Dunning and R. Narula (Eds.), Foreign direct investment and government catalysts for economic restructuring. London, Routledge.

Felipe, J. (1997). Total factor productivity growth in East Asia: A critical survey, economics and development research center report series No. 65, Asian Development Bank.

IMF. (2017). Balance of payments analytic presentation by country, IFS, https://www.imf.org/en/Data

Jarolim, M. (2000). Foreign direct investment and productivity of firms. Finance a úvěr-Czech Journal of Economics and Finance, $50(9), 487$.

Johansen, S. (1998). Statistical analysis of cointegration vectors. Journal of Economic Dynamics and Control, 12(3), $231-254$.

Kosztowniak, A. (2017). Economic growth model for the Czech Republic and FDI inflow significance-OLS method examples. In: Vopova, J., Douda, V., Kratochovil, R., \& Konecki, M. (eds.), Multidisciplinary Academic Conference on Management, Marketing and Economics, MAC Prague consulting s. r. o., Czech Republic, pp. 259-267.

Landesmann M. A. (2003). Structural features of economic integration in an enlarged Europe: Patterns of catching-up and industrial specialisation. European Economy No.181. European Commission, Brussels, p. 1-62.

Nikolovová, P. (2013). Sourcing patterns of FDI activity and their impact on the domestic economy. Finance a úvěr-Czech Journal of Economics and Finance, 63(3), 300-301.

OECD.Stat. (2017). Data by theme, http://stats.oecd.org

Ozturk, I. (2007). Foreign direct investment-growth nexus a review of the recent literature. International Journal of Applied Econometrics and Quantitative Studies, 4(2), 93-110.

Solow, R. M. (1999). Neoclassical growth theory. In J. B. Taylor and M. Woodford (Eds.), Handbook of macroeconomics. Amsterdam: Elsevier.

UNCTAD.Sta. (2017). http://unctadstat.unctad.org 